Available online on 15.02.2020 at http://jddtonline.info
Open Access to Pharmaceutical and Medical Research
unrestricted non-commercial use, provided the original work is properly cited

Open 2 Access

Research Article

\title{
Determination of microbial load, total Phenolic and flavonoids contents in polyherbal formulation "yograj guggulu vati"
}

\author{
Vimal Dutt ${ }^{1}$, Shivani Srivastav ${ }^{1}$, Swati Mittal ${ }^{2}$, Md Rafiul Haque ${ }^{1 *}$ \\ ${ }^{1}$ Department of Pharmacognosy, HIMT College of Pharmacy, Knowledge Park-1, Gr. Noida (U.P), India \\ 2 Department of Pharmaceutics, HIMT College of Pharmacy, Knowledge Park-1, Gr. Noida (U.P), India
}

\begin{abstract}
Yograj guggulu vati (YGV), a polyherbal formulation is recommended for the management of diseases like arthritic, anodyne or analgesic, spasm, muscle relaxant, flatulence, digestive problem, cough, hyperglycaemia, fat burner and obesity. Though Yograj guggulu vati is widely used for the treatment of diseases in Ayurvedic System of Indian Medicine, but till date, it's Phenolic and flavonoids contents and contamination studies have not been carried. In the present article, we evaluated the total phenolic and flavonoids contents and contamination of YGV. Total phenolic contents were evaluated by Folin Ciocalteu reagent. Aluminum chloride colorimetric method was used for the determination of total flavonoid contents. Contamination study such as microbial load was also performed. Microbial load study revealed that total bacterial counts and total fungal counts were under limits. The total phenolic content and total flavonoid content were $190.16 \mathrm{mg} / \mathrm{g}$ and $20.87 \mathrm{mg} / \mathrm{g}$ dry extract respectively. Microbial load studies showed that the formulation has a good quality and purity. Presence of abundance phenolic and flavonoids compound indicated that YGV can be used for different biological activities.
\end{abstract}

Keywords: Microbial load, Yograj Guggulu Vati, total phenolic contents

Article Info: Received 19 Nov 2019; Review Completed 07 Jan 2020; Accepted 16 Jan 2020; Available online 15 Feb 2020

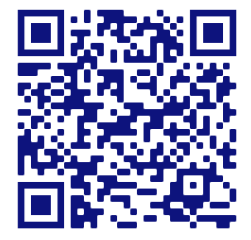

Cite this article as:

Dutt V, Srivastav S, Mittal S, Haque MR, Determination of microbial load, total Phenolic and flavonoids contents in polyherbal formulation "yograj guggulu vati” , Journal of Drug Delivery and Therapeutics. 2020; 10(1-s):1-5 http://dx.doi.org/10.22270/jddt.v10i1-s.3858

Department of pharmacognosy, HIMT College of Pharmacy, Knowledge Park-1, Gr. Noida (U.P), India

\section{INTRODUCTION}

Guggulu is an oleo gum resin exudates from the stem of Commiphora wightii (Hook ex. Stocks), belonging to family burseraceae. It is known to have analgesic, lipid lowering action and anti- inflammatory properties ${ }^{1}$. Guggulu is the principal ingredient of Yogaraja guggulu formulations. It is also the principal ingredient of several formulations such as Rasnadi guggulu, Vatari guggulu and Vayusadi guggulu etc are traditionally used for musculoskeletal problems, body pain, osteoarthritis, obesity, sciatica and rheumatoid arthritis etc ${ }^{2}$. The preparation of yogaraja guggulu vati (YGV) is based on traditional method mentioned in the Ayurvedic Pharmacopoeia of India. It is prepared from 28 ingredients and it is shown in table 1 . It has been investigated that YGV has good quality, strength and purity². Agarwal et al. 2018 investigated that YGV did not contain heavy metals (Lead and Cadmium) more than prescribed limits. Phenolic and flavonoids compound of the polyherbal formulations and crude drug are important to justify its acceptability in the modern system of medicine. It has been reported that the greater amount of phenolic and favonoid compounds leads to more potent antioxidant (free radical scavenging) effect. Many published data reveals that the various biological actions of herbal product and compounds formulations are related to their antioxidant activity ${ }^{3}$. World Health Organization (WHO) has emphasized the need to ensure microbial contamination of polyherbal formulations and herbal products using modern techniques and applying appropriate standards. The present work is carried out to determine total phenolic and flavonoids contents and also evaluate microbial contamination of YGV. 
Table 1. Composition of YGV

\begin{tabular}{|c|c|c|c|c|}
\hline S.no & Ingredients & Botanical name & Part used & Quantity \\
\hline 1 & Pippalimula API & Piper longum & Rt. & 1 PART \\
\hline 2 & Yamani API & Trachyspermum ammi & Sd. & 1 PART \\
\hline 3 & Karavi & Carum carvi & Fr. & 1 PART \\
\hline 4 & Vidariga API & Embelia ribes & Fr. & 1 PART \\
\hline 5 & Ajamoda API & Apium leptophyllum & Fr. & 1 PART \\
\hline 6 & Jiraka & Cuminum cyminum & Fr. & 1 PART \\
\hline 7 & Suradaru & Cedrus deodara & & 1 PART \\
\hline 8 & Cavya API & Piper chaba & St. & 1 PART \\
\hline 9 & Ela & Eiettaria cardamomum & Sd. & 1 PART \\
\hline 10 & Saindhava lavana API & Rock salt & & 1 PART \\
\hline 11 & Kustha API & Saussurea lappa & Rt. & 1 PART \\
\hline 12 & Rasna API & Pluchea lanceolata & Rt./Lf. & 1 PART \\
\hline 13 & Goksura API & Tribulus terrestris & Fr. & 1 PART \\
\hline 14 & Dhanyaka API & Coriandrum sativum & Fr. & 1 PART \\
\hline 15 & Haritaki API & Terminalia chebula & p. & 1 PART \\
\hline 16 & Bihitaka API & Terminalia belerica & p. & 1 PART \\
\hline 17 & Amalaki API & Emblica officinalis & p. & 1 PART \\
\hline 18 & Mustaka & Cyperus rotundus & Rz. & 1 PART \\
\hline 19 & Sunthi API & Zingiber officinale & Rz. & 1 PART \\
\hline 20 & Marica API & Piper nigrum & Fr. & 1 PART \\
\hline 21 & Pippali API & Piper longum & Fr. & 1 PART \\
\hline 22 & Tvak API & Cinnamomum zeylancium & St. Bk. & 1 PART \\
\hline 23 & Uisra API & Vetiveria zizanoides & Rt. & 1 PART \\
\hline 24 & Yavagraja ksara API & Hordeum vulgare & Pl. & 1 PART \\
\hline 25 & Talisa patra API & Taxus wallichii & Lf. & 1 PART \\
\hline 26 & Patra & Cinnamomum tamala & Lf. & 1 PART \\
\hline 27 & Guggulu API-Suddha & Commiphora wightii & O.R. & 27 PART \\
\hline 28 & Sarpi & Clarified butter & & $\underline{\mathbf{Q S}}$ \\
\hline
\end{tabular}

\section{MATERIALS AND METHODS}

\section{Procurement of YGV}

It was procured from local market at the month of January. The tablets were looking good and non-sticky. The colour and shape of tablets were analysed with naked eye.

\section{Determination of total phenolic contents (TPC)}

Total phenolic contents (TPC) of the YGV extracts obtained in methanol were estimated using Folin Ciocalteu assay by colorimetric method. YGV extracts with various concentrations $(25 \mu \mathrm{l}, 50 \mu \mathrm{l}, 75 \mu \mathrm{l}, 100 \mu \mathrm{l}, 125 \mu \mathrm{l}, 150 \mu \mathrm{l}, 175 \mu \mathrm{l}$, $200 \mu \mathrm{l}, 225 \mu \mathrm{l}$ and $250 \mu \mathrm{l}$ ) were mixed with $1 \mathrm{ml}$ of Folin Ciocalteu phenol reagent $(1 \mathrm{ml})$ and incubated room temperature for 3 minutes, followed by $1 \mathrm{ml}$ of $20 \%$ sodium carbonate solution was added to mixture and diluted to 10 $\mathrm{ml}$ with purified water. The reaction mixtures were incubated in dark for one hour and the absorbance of the resulting blue color was measured at $765 \mathrm{~nm}$ with Shimadzu UV-VIS Spectrophotometer ${ }^{4}$. Quantifications were done with respect to the standard curve of Gallic acid $(20-100 \mu \mathrm{g} / \mathrm{ml})$. Results were expressed as mg of. Gallic acid equivalent per $100 \mathrm{~g}$ of the dry weight of the YGV extracts (GAEs). All determinations were performed in triplicates $(n=3)$. The standard curve of gallic acid is shown in figure 1.

\section{Determination of total flavonoid contents (TFC)}

TFC of the YGV extracts were determined by Aluminum chloride colorimetric assay. YGV extracts with different concentrations $(10 \mu \mathrm{l}, 20 \mu \mathrm{l}, 40 \mu \mathrm{l}, 50 \mu \mathrm{l}$ and $100 \mu \mathrm{l})$ were prepared and mixed with $1.25 \mathrm{ml}$ of distilled water and $75 \mu \mathrm{l}$ of $5 \%$ sodium nitrite solution was added. After 5 minutes $150 \mu \mathrm{l}$ of $10 \% \mathrm{AlCl}_{3} \mathrm{H} 2 \mathrm{O}$ solution was added. After 6 minutes $500 \mu \mathrm{l}$ of $1 \mathrm{M}$ sodium hydroxide and $275 \mu \mathrm{l}$ of distilled water were added to the mixture. The solution was mixed well and the absorbance was measured against a freshly prepared reagent blank at $510 \mathrm{~nm}^{4}$. The standard curve of quercetin is shown in figure 2 .

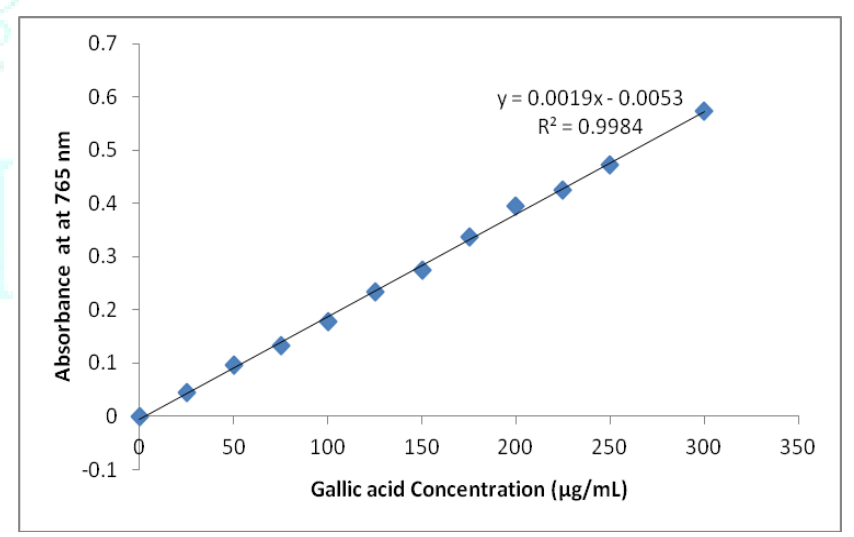

Figure 1. The standard curve of gallic acid

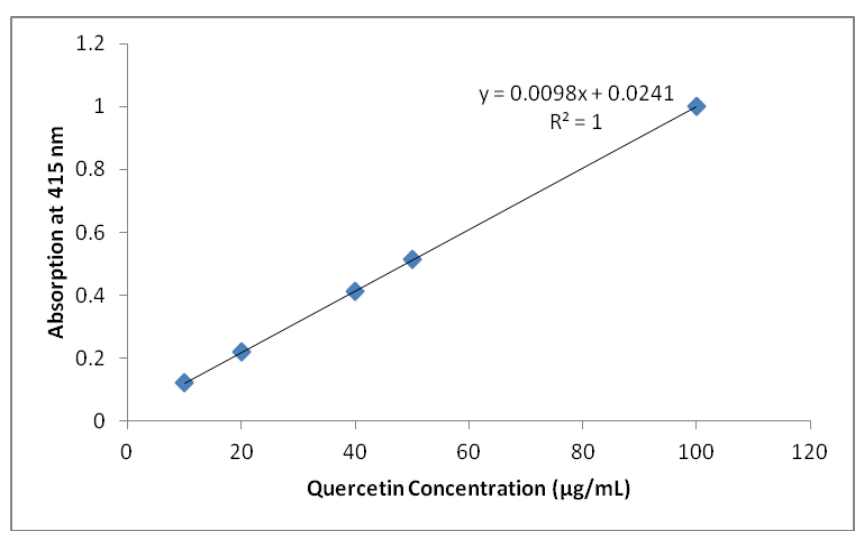

Figure 2. The standard curve of quercetin 


\section{Determination of microbial counts explained as per WHO}

$1 \mathrm{gm}$ of drug was taken and suspended in $50 \mathrm{ml}$ distilled water. The suspension was shaken for sufficient period of time so as to allow maximum mixing. After this suspension was filtered using disposable sterilized filter paper. The filtrate was used as stock solution. Series dilution $(1: 1,1: 10$ $1: 100$ ) of this stock solution were made $1 \mathrm{ml}$ of different diluted solution was separately inoculated (with spreading method) on a nutrient agar medium and incubated at $37{ }^{\circ} \mathrm{C}$ for 24 hours. After 24 hours, the petri-plates with clear colonies were taken and number of colonies determined by using colony counter. The dilution load per gram of sample was then calculated by using dilution factor. The composition of nutrient medium is shown in table 2 . The medium was autoclaved at $151 \mathrm{lbs}$ per square inch pressure at $121^{\circ} \mathrm{C}$. The growth of microbial in petri-plates dish is shown in figure 3 .

Table 2. Composition of nutrient agar medium

\begin{tabular}{lll}
\hline S.No & Ingredients & contents \\
\hline 1 & Agar & $15 \%$ \\
2 & Peptide digest of animal tissue & $5.0 \%$ \\
3 & Sodium chloride & $5.0 \%$ \\
4 & Beef extract & $1.5 \%$ \\
5 & Yeast extract & $1.5 \%$ \\
6 & PH & $7.4 \pm 0.2$ AT $25 \mathrm{C}$ \\
7 & Distilled water & $1000 \mathrm{ml}$ \\
\hline
\end{tabular}

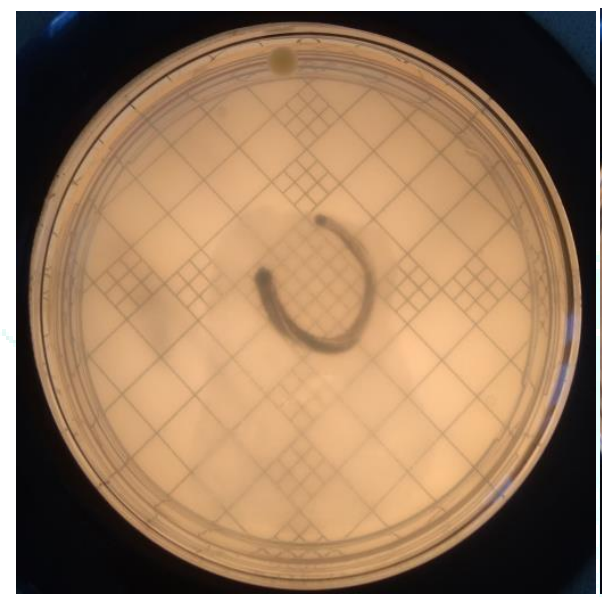

Control

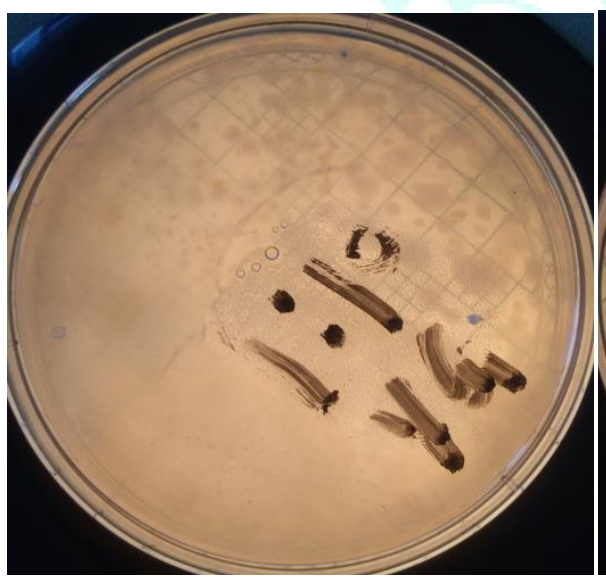

(1:10)

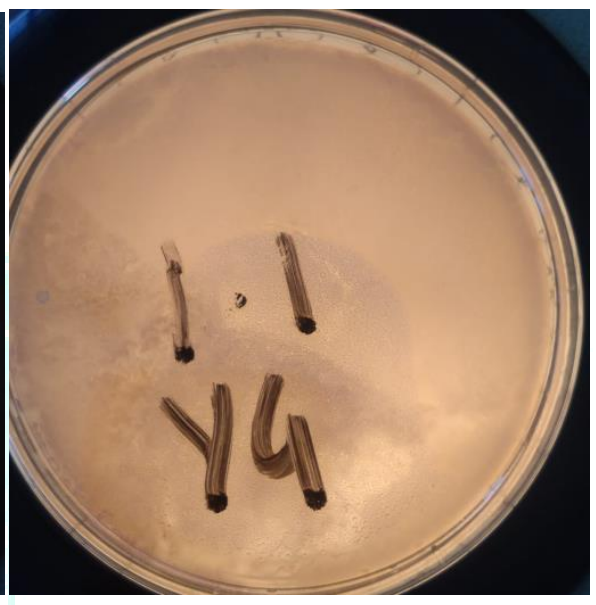

(1:1)

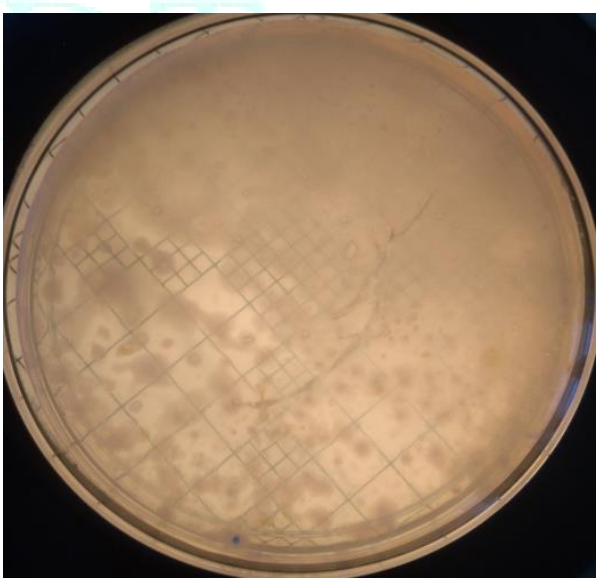

(1:100)

Figure 3. The growth of microbials in petri plates in different dilution.

\section{Physico- chemical properties}

The physico-chemical parameters such as ash value, extractive value, LOD and PH were evaluated as per methods of Ayurveda Pharmacopiea of India 5 .

\section{Tablet parameters}

All tablet parameters such as diameter and thickness, weight variation, hardness, friability and disintegration were evaluated as per described in Indian Pharmacopoeias (IP) ${ }^{6}$. 


\section{RESULT AND DISCUSSION}

YGV is a traditional Ayurvedic preparation prescribed for wide range of disorders. In this work an attempt has been made to determine total phenolic content, total flavonoid content and microbial load. The physico- chemical properties and tablet testing parameters of YGV were also evaluated.

\section{Total phenolic contents and flavonoid contents}

The total phenolic content and flavonoid content were found to be $190.16 \mathrm{mg} / \mathrm{g}$ and $20.87 \mathrm{mg} / \mathrm{g}$ dry extract respectively. Phenols are very important plant constituents because of their radical scavenging ability due to their hydroxyl groups $4,7,8$. Phenolic compounds are a class of antioxidant agents which act as free radical terminators. Flavonoids are a group of polyphenolic compounds with known properties which include free radical scavenging, inhibition of hydrolytic and oxidative enzymes and anti-inflammatory action. Some evidence suggests that the biological actions of these compounds are related to their antioxidant activity 9, 10. Free radicals are involved in many disorders like neurodegenerative diseases, cancer and AIDS. Antioxidants through their scavenging power are useful for the management of those diseases. It has been recognized that flavonoids show antioxidant activity and their effects on human nutrition and health are considerabl11. The mechanisms of action of flavonoids are through scavenging or chelating process 12,13 .

\section{Physico-chemical parameters}

The physical parameters such as ash value, extractive value, LOD and PH were found under pharmacopeial limits (It is shown in table 3). Sample was found to be in prescribed range (pharmacopeial limits) for total ash $(5.23 \% \mathrm{~W} / \mathrm{W}$, acid insoluble ash $(0.8 \% \mathrm{~W} / \mathrm{W})$, alcohol extractive $(17.57 \%$ $\mathrm{W} / \mathrm{W})$, water extractive $(23.4 \% \mathrm{~W} / \mathrm{W}), \mathrm{LOD}(6.7 \% \mathrm{~W} / \mathrm{W})$ and PH (5.1). The results from physico- chemical parameters indicated that the marketed preparation had good quality, stregnth and purity.

Table 3. Compared with standard

\begin{tabular}{|l|l|l|l|}
\hline S.No & Parameters & Observed Value & Pharmacopeia limit \\
\hline 1 & LOD & $6.7 \% \mathrm{~W} / \mathrm{W}$ & NMT $10 \% \mathrm{~W} / \mathrm{W}$ \\
\hline 2 & Total Ash & $5.23 \% \mathrm{~W} / \mathrm{W}$ & NMT $6 \% \mathrm{~W} / \mathrm{W}$ \\
\hline 3 & Acid insoluble ash & $0.8 \% \mathrm{~W} / \mathrm{W}$ & NMT $1 \% \mathrm{~W} / \mathrm{W}$ \\
\hline 4 & Alcohol extractive & $17.57 \% \mathrm{~W} / \mathrm{W}$ & NLT $16 \% \mathrm{~W} / \mathrm{W}$ \\
\hline 5 & Water extractive & $23.4 \% \mathrm{~W} / \mathrm{W}$ & NLT $19 \% \mathrm{~W} / \mathrm{W}$ \\
\hline 6 & PH (1\%) & 5.1 & $4.7-5.2$ \\
\hline
\end{tabular}

\section{Microbial load determination}

Many pathogens microbes such as Spirochete, Escherichia coli, Shigella, Salmonella, Enterobacter, Klebsiella, Citrobacter, Novoviruses, enteric hepatitis viruses, gastroenteritis viruses, enteroviruses and parasitic worms are present in water 14, 15. In addition, different kinds of moulds such as Aspergillus spp. Penicillium spp. are also present in water that are usually allergic and toxigenic 16 . These fungi are not only accountable for the adverse effects on health but also cause taste and odour problems in drinking water ${ }^{17}$. YGV sample showed very less development microbial growth in 1:1(10 CFU), 1:10 (100 CFU) and 1:100 (220 CFU) dilutions which were under limits. From the results of microbial load revealed that the sample formulation has antimicrobial action that is why it inhibited the growth of microbes.

\section{Results of tablet testing parameters}

The thickness of tablets was performed on 20 tablets from each formulation. Digital Vernier caliper was used for the study, which permits accurate measurements and provides information of the variation between tablets. The thickness of tablets was found and $4.5 \mathrm{~mm}$. It is shown in Table 4 . Weight variation was carried out to ensure that, each of tablets contains the proper amount of drug. The test was carried out by weighing the 20 tablets individually using analytical balance, then calculating the average weight, and comparing the individual tablet weights to the average 6 . Weight variation of sample was found to be -0.16 to $+0.09 \%$ $\mathrm{W} / \mathrm{W}$. It is shown in Table. The resistance of tablets to capping, abrasion or breakage under conditions of storage, transportation and handling before usage depends on its hardness. Tablet hardness is defined as the load required crushing or fracture a tablet placed on its edge. Sometimes it is also termed as tablet crushing strength. The hardness test was performed using Monsant type (Make: Singhla) hardness tester. The instrument measures the force required to break the tablet when the force generated by anvils to the tablet. The tablet was placed between two anvils; force applied to the anvils, and the crushing strength that just causes the tablet to break was recorded. The crushing strength test was performed on 20 tablets from each formulation. The hardness of vati was found $5.3 \mathrm{~kg} / \mathrm{cm}^{2}$. For each formulation, the friability of 20 tablets was determined using Roche type friabilator. 20 tablets from each formulation were weighed and tested at a speed of $25 \mathrm{rpm}$ for $4 \mathrm{~min}$. After removing of dusts, tablets were re-weighed, and friability percentage was calculated using the following equation. The friability of sample was found to be $9.9 \%$ W/W. The disintegration apparatus, described in I.P was used for the study. It contains 2 basket rack assembly. Each basket rack assembly consists of 6 glass tubes that are 3 inches long, open at the top and held against 10 mesh screens at the bottom. Each tablet was placed in each tube, and the basket rack was positioned in 1-L beaker of distilled water. The $37 \pm 2^{\circ} \mathrm{C}$ temperature was maintained throughout the study. The average disintegration time of sample was found to be 5.1 minutes $^{6}$. The results are shown in table 4 . 
Table 4. Result of tablet parameters

\begin{tabular}{lll}
\hline S. No & Parameters & Observed value \\
\hline 1 & Hardness & $5.3 \mathrm{Kg} / \mathrm{cm}^{2}$ \\
2 & Thickness & $4.5 \mathrm{~mm}$ \\
3 & Average wt & $390 \mathrm{mg}$ \\
4 & Weight variation & $-0.16 \mathrm{to}+0.09 \% \mathrm{~W} / \mathrm{W}$ \\
5 & Friability & $9.9 \% \mathrm{~W} / \mathrm{W}$ \\
6 & Disintegration & $5.1 \mathrm{~min}$ \\
\hline
\end{tabular}

\section{CONCLUSIONS}

The result of the present study showed that the extract of YGV, which contain highest amount of flavonoid and phenolic compounds, it may exhibit the greatest antioxidant activity. The marketed sample showed good quality, purity and less development of microbial contamination and the results from different physico-chemicals and tablet testing parameters may be differentiating features from many other Vati formulations of Guggulu.

\section{ACKNOWLEDGEMENT}

Authors are thankful to Department of Pharmacognosy and Phytochemistry, HIMT College of Pharmacy for providing all necessary facilities for this work.

CONFLICT OF INTEREST: None declared.

\section{SOURCE OF SUPPORT: Nil}

\section{REFERENCES}

1. Shalini, Prajapati PK, Harisha CR., Pandya DH. Quality control parameters of vatari guggulu- an ayurvedic formulation. International Journal of Ayurveda and Pharma Research. 2016; 4(6): 13-18

2. Agarwal P, Vaishnav, R Ranawat MS. Evaluation of Quality Parameters of Three Different Marketed Brands of Yogaraj Guggulu Vati: A Polyherbal Formulation. Biomedical Journal of Scientific \& Technical Research. 2018; 6(4):53555361.

3. Haque MR, Ansari SH, Najmi AK, Ahmed MA. Monoterpene phenolic compound thymol prevents high fat diet induced obesity in murine model. Toxicology Mechanisms and Methods 2014; 24 (2) :115-22

4. Pourmorad F, Hosseinimehr SJ, Shahabimajd N. Antioxidant activity, phenol and flavonoid contents of some selected Iranian medicinal plants. African Journal of Biotechnology. 2006; 5: 1142-1145.

5. Anonymous. The Ayurvedic Pharmacopoeia of India (API), Part - II (Formulations) Volume - II, First Edition Government Of India, Ministry of Health And Family Welfare Department Of Ayurveda, Yoga \& Naturopathy, Unani, Siddha And Homoeopathy,New Delhi 2008.

6. Anonymous. Indian Pharmacopoeia (IP) seventh edition, the Indian Pharmacopoeia Commission (IPC) the Government of India, Ministry of Health \& Family Welfare 2014.

7. Chang, C., Yang, M., Wen, H., Chern, J., 2002. Estimation of total flavonoid content in propolis by two complementary colorimetric methods. J. Food Drug Analaysis, 10, 178-182.

8. Hayat K, Zhang X, Farooq U, Abbas S, Xia S, Jia C. Effect of microwave treatment on phenolic content and antioxidant activity of citrus mandarin pomace. Food Chemistry. 2010; 123: 423-429

9. Chu Y. Flavonoid content of several vegetables and their antioxidant activity. Journal of the Science of Food and Agriculture. 2000; 80, 561 - 566.

10. MR Haque, SH Ansari, AK Najmi, KJ Naquvi. Validated HPTLC analysis method for quantification of thymol content in Trachyspermum ammi and polyherbal Unani formulation arq zeera. International Journal of Pharmacy and Pharmaceutical Sciences. 2012; 4 (3): 478-482.

11. Gryglewski RJ, Korbu T, Robak J. On the mechanism of antithrombotic action of flavonoids. Biochemical pharmacology. 1987; 36: 317- 321.

12. Kessler M, Ubeaud G, Jung L. Anti- and pro-oxidant activity of rutin and quercetin derivatives. Journal of pharmacy and pharmacology. 2003; 55: 131- 142.

13. Cook NC, Samman S. Flavonoids- chemistry, metabolism, cardioprotective effects, and dietary sources. Journal of Nutritional Biochemistry.1996; 7: 66- 76.

14. Bharti AR, Nally JE, Ricaldi JN, Matthias MA, Diaz MM, Lovett MA, Levett PN, Gilman RH, Willig MR, Gotuzzo E. \& Vinetz JM. Leptospirosis: a zoonotic disease of global importance. Lancet Infectious Diseases. 2003; 3: 757-571.

15. Bosch A. Human viruses in water. Elsevier Science, Amsterdam.2007; 306.

16. Hageskal G, Gaustad P, Heier BT \& Skaar I. Occurrence of molds in drinking water. Journal of Applied Microbiology. 2006; 102:774-780.

17. Haque MR, Ansari SH, Naquvi KJ and Najmi AK.Quality Assessment of a traditional Unani Formulation Arq Zeera. Journal of Pharmacy Research 2012; 5(2):778-782. 